\title{
Fények és árnyak Sherwin B. Nuland Semmelweis-képén
}

\author{
Kiss László dr.
}

A magyar millennium alkalmából 2001-ben jelent meg Gazda István tudománytörténész (Magyar Tudománytörténeti Intézet) által sajtó alá rendezett „Semmelweis Ignác emlékezete". A két kötetből álló kiadvány anyagát összeválogató orvostörténész, Szállási Árpád arra törekedett, hogy az olvasó komplex képet nyerhessen „az anyák megmentője”-ként világszerte tisztelt magyar orvos életútjáról, életmúvéről. E teljességhez hozzá tartozik Semmelweis patográfiája is („a Semmelweis-probléma") s annak legfontosabb kérdése: szenvedett-e egyáltalán elmebetegségben Semmelweis, s ha igen, ez a szifilisz okozta progresszív paralízis volt-e? A válogatás újraközli a korábbi viták legfontosabb megállapításait. Mintegy a viták lezárásának tekinthető - legalábbis a szerzőpáros: Magyar István-Zoltán Imre annak szánták - a „Még egyszer Semmelweis betegségéról (Utoljára?)” címü, 1992-ben megjelent dolgozat [1]. „Reméljük, hogy végre pontot tehetünk a vele kapcsolatos egyetlen, eddig még befejezetlen mondat végére..." - s e reményük fó pillére egy 1989-ben(!) megjelent könyv, amelyet Sherwin B. Nuland, „a connecticuti Yale Egyetemen az orvostörténet tanára” írt „Orvosok, az orvostudomány életrajza" címmel.

A magyar orvostársadalom itt találkozhat először Nuland nevével. (Egyes orvostörténészeink természetesen már jóval korábbról ismerik őt.) A Magyar-Zoltán szerzópáros Nuland „Doctors, the Biography of Medicine” 1988-ban - s nem 1989-ben - New Yorkban megjelent könyvének 9., Semmelweisről szóló fejezetében vélte megtalálni a Semmelweis-probléma befejezetlen mondatát lezáró pontot. „Nuland történelmi hűséggel írja meg Semmelweis élettörténetét, majd betegségével foglalkozik" - véli a magyar szerzőpáros -, s ez utóbbival kapcsolatban azt írják, hogy Nuland - lévén jómaga nem pszichiáter - „erre a Yale Egyetem neuropatológiai intézetének igazgatóját, Elias Manuelidis professzort kéri fel. Manuelidis részletesen írja le elemzésének módját és részeredményeit, végül határozott diagnózist mond: Semmelweisnek nem volt syphilise, betegsége Alzheimer-kór volt.”

Nos, Nuland „történelmi hűségéről” még lesz alkalmunk véleményt olvasni, most csupán arra hívom fel a figyelmet, hogy Nuland eredeti szövegét átolvasva, abban nem találtam a magyar szerzőpáros által „részletesnek" aposztrofált betegségelemzést. Nuland könyve vál- tozatlan szöveggel, ám illusztrálva, 2008-ban újra megjelent - ebből idézem a Manuelidis szakvéleményére utaló részt: „From the available published materials, Manuelidis... feels sure that there is not sufficient evidence to indicate syphilis... He suggest that the organic condition may have been one not yet described in 1865 : Alzheimer's presenile dementia; the clinicopathological picture of wich is in many way more consistens with the published descriptions and photographs of Semmelweis' symptoms and autopsy findings than syphilis" [2].

Már az idézett szövegből is kiderül, hogy Manuelidis nem volt Semmelweis-kutató. Nuland 2003-ban kiemelte saját könyvéből a Semmelweis-fejezetet és azt kibővítve „The Doctors' Plague - Germs, Childbed Fever, and the Strange Story of Ignác Semmelweis" címmel önálló kötetben is kiadta. A kötet 2013-ban, Garai Attila fordításában, magyarul is megjelent. Ebból idézem Nuland és a neuropatológus együttmúködésének adatait: „Csak a beteg életkorát közöltem vele, és azt, hogy a 19. század közepén halt meg, majd elmeséltem, milyen tünetek jelentkeztek nála élete utolsó éveiben. Dr. Manuelides (!) egyértelmúen kijelentette, hogy a szifilisz diagnózisát a rendelkezésre álló információk nem támasztják alá, és sokkal valószínúbb kórmeghatározást javasolt, bár azt csak 1907-ben írták le először. Azt mondta, mindaz, amit az esetről megtudott, teljes mértékben összeegyeztethető a "preszenilis « (viszonylag korán, nem idős korban kezdődő) Alzheimer-demencia diagnózisával. Különösen meggyőző volt az a mozzanat, amelyre az idáig nem figyeltem fel, nevezetesen, hogy a beteg alig négy év leforgása alatt látványosan megöregedett, ami ennél a betegségnél jellegzetes tünet” [3].

Nem kívánom kétségbe vonni a görög szülőktől Konstantinápolyban (ma: Isztambul) született, 1942-ben Münchenben doktori oklevelet szerzett, majd 1964-tôl a Yale Egyetemen mint „professor of pathology” (kórbonctantanár) működő Elias Emmanuel Manuelidis (1918-1992) szakmai tudását, felkészültségét. Nemzetközileg elismert kísérletező kutatója volt az agy vírus okozta betegségeinek, a Creutzfeld-Jakob-betegségnek, az Alzheimer-kórnak [4]. Nem volt azonban klinikus, a neuropatológusként kutatott betegségeknek csak a szövettanát ismerhette. Bizonyára készségesen meghallgatta fiatalabb sebész kollégája „mesélését” a számára ismeretlen magyar orvosról, megtekinthette a Nuland-könyvek- 
ben ismételten bemutatásra kerülő, 1857-ből és 1861ből származó Semmelweis-portrék másolatait, s aztán mondott egy véleményt. Nuland pedig e véleményre építette a Semmelweis betegségérôl alkotott föltevését (hipotézisét) 1977-ben és görcsösen ragaszkodott hozzá a 2014-ben bekövetkezett haláláig. Márpedig „a föltevések nem bizonyítanak semmit, csak arra jók, hogy az ember megpihenhessen, hogy megnyugodjon valahogyan, amikor már apróra törte a fejét, mert ki akar találni valamit, amit nem lehet kitalálni” - állítja Nuland földije, a szépíró Mark Twain [5]. A teljesség kedvéért: Nuland 1994-ben New Yorkban kiadott „Ho we die” címü könyvében külön fejezetet szentel az Alzheimer-kórnak, ebben azonban egyszer sem említi Semmelweis nevét. (Könyve 2002-től, Pécsi Tibor fordításában s az Akkord Kiadó jóvoltából magyarul is olvasható: „Hogyan halunk meg? Gondolatok az élet utolsó fejezetéról” címmel.)

Az 1930-ban, New Yorkban született Nulandnak - tudomásom szerint - nem volt (orvos)történészi képzettsége. A Yale Egyetem Orvosi Karának sebészprofesszoraként kezdett érdeklődni az 1970-es években szakmájának/hivatásának múltja iránt. Kutakodásainak fó színhelye egyetemének 1941-ben megnyitott orvostörténeti könyvtára volt. Itt volt alkalma találkozni a hasonló érdeklődésű kollégákkal, akik közül külön kiemeli „Ferenc Gyorgyey”-t, a könyvtár későbbi igazgatóját. A már említett, 1988-ban kiadott „Doctors...” címú könyve az angol szövegbe iktatott „Köszönöm kedves barátom!" magyar szavakkal állít emléket Györgyey $F e^{-}$ rencnek [6]. Az idén 90. életévét betöltött Györgyey Ferenc Aladár 1925. március 14-én Budapesten született. Bölcsészkari végzettséggel az 1948 és 1956 közti éveket különféle internálótáborokban - többek közt Recsken töltötte; erre emlékezik az 1990-ben Budapesten kiadott "Lágerhumor" című memoárja. Emigrált és New Havenben, Connecticutban telepedett le, ahol az 1707-ben alapított Yale Egyetemen orvostörténészi diplomát szerzett. Disszertációját a gyermekágyi lázról írta: „Puerperal fever, 1847-61”. 1968-tól nyugalomba vonulásáig, 1994-ig a már említett orvostörténeti könyvtár igazgatója. 1974-ben részt vett a Nemzetközi Orvostörténeti Társaság XXIV. kongresszusán, Budapesten. Ekkor kötött barátságot Antall Józseffel. E barátságra emlékezve, Antall halála után, a Semmelweis Orvostörténeti Múzeum, Könyvtár és Levéltár Történeti Dokumentációs Gyújteményének 73 múból (76 kötet) álló sorozatot ajándékozott [7].

Amikor Nuland esszéket kezd írni a híres orvos elődökről, közülük Semmelweis nem maradhat ki. A már említett, 2003-ban kiadott - és tíz évvel később magyarra is lefordított - Semmelweis-könyvében így emlékezik a kezdetekre [3]: „Engem több mint 25 évvel ezelőtt rabul ejtett Semmelweis Ignác egyénisége. Az életével való közelebbi megismerkedésemet követően a Yale Egyetem sebészettörténeti sorozata keretében tartottam róla előadást 1978 februárjában. Ezt követően, 1979ben jelent meg a Journal of the History of Medicine and
Allied Sciences hasábjain a »The Enigma of Semmelweis - An Interpretation« (A Semmelweis-rejtély lehetséges értelmezése) címú tanulmányom. Ez a cikk - mint néhány évvel később a budapesti Semmelweis Orvostörténeti Múzeum, Könyvtár és Levéltárban tett látogatásomkor kiderült számomra - zavart keltett Semmelweis néhány rajongójában, akik a magyar orvoslás nemzeti hősének emlékét ápolták. Többen is kifogásolták, miként jellemeztem Semmelweist, különösen személyisége önpusztító vonásait illetően értek vádak. Senki sem jelezte, hogy teljesen egyetért az Alzheimer-kór diagnózisával, holott az már akkor magától értetődőnek tűnt - és annak tünik ma is. Máig sem értem, miért volt vendéglátóim számára a szifilisz diagnózisa elfogadhatóbb... A heves magyarországi ellenvéleményekkel szembesülve annyira megbizonyosodtam az igazamról, hogy a tanulmányt újból megjelentettem az 1988-ban kiadott, laikusoknak szóló orvostörténeti kötetemben..." (192-193. o.). És e tanulmány képezte alapját a 2003-ban kiadott könyvnek is, hiszen mint Nuland a „Bibliográfia jegyzetek” fejezetben írja: „Az abban közölt főbb érveimet máig érvényesnek tartom, és igazukról jobban meg vagyok győződve, mint valaha" (193. oldal).

Az említett budapesti (és bécsi) látogatásra 1985-ben került sor. Valószínúleg magánemberként kereste fel a Semmelweis Orvostörténeti Könyvtárat - hogy kivel/ kikkel találkozott Budapesten, arról nem sikerült írásbeli nyomot találnom. Valószínű azonban, hogy nem találkozott azzal a személlyel, akivel leginkább találkoznia kellett volna: Benedek Istvánnal (1915-1996). A „Semmelweis és kora” (Gondolat Kiadó, 1967) és „Semmelweis” (Gondolat Kiadó, 1980) című monográfiáival már nemzetközi hírű Semmelweis-kutatónkkal lett volna miről eszmét cserélnie Nulandnak. Benedek ugyanis már Nuland első, 1979-es, a Journal of the History of Medicine hasábjain megjelent, a Semmelweis-rejtélyt taglaló írására levélben reagált. A levél - Györgyey Ferenc fordításában - angol nyelven jelent meg az Orvostörténeti Közleményekben 1980-ban, Nuland válaszával együtt [8].

Nuland tézisét, tudnillik a semmelweisi sors szophoklészi értelmezését - „bukását” saját magában, s nem külső tényezőkben kell keresni - Benedek eredetinek tartja, bár megjegyzi, hogy hasonló értelmezés már korábban is felmerült, azt azonban Nuland nem ismerhette. S bár Nuland 16 oldalas esszéje nem mond semmi újat a magyarok számára, hasznos lehet(ne) a Semmelweisról alig halló nem magyarok számára - véli Benedek -, ha nem tartalmazna tévedéseket és egyoldalú, felületes vélekedéseket. Különösen igaztalannak tartja Benedek Nuland Semmelweist bemutató jelzőit: „awkward and clumsy”, illetve azon állítását, hogy Semmelweis mind Bécsben, mind Pesten csak „outsider” lehetett. Nuland inkomplett és egyoldalú informáltságából fakadnak az olyan téves állítások, mint hogy Hebra közeli barátja volt Semmelweisnek, illetve, hogy Semmelweist a bécsi akadémia tagjává választotta. Végül felhívja Nuland figyelmét, hogy az Alzheimer-kór diagnózisa azért nem fogadható 
el, mert e kór legfontosabb tünetei (demencia, fokális agyi tünetek: afázia, apraxia, agnózia) nem mutathatók ki Semmelweis kórképében. Utolsó ajánlásként azt tanácsolja Nulandnak: olvassa el Semmelweis Aetiologiáját.

Válaszában Nuland azon csodálkozik, miért hökkenti meg a helybelieket, ha „nemzeti hősüket” nemcsak ismerik más országokban, de nagyra is becsülik. S miért kell feltételezni, hogy nem olvastuk Semmelweis nagy múvét? Szerinte igenis vannak amerikaiak, akik többet tudnak a Monarchiáról és a korabeli időkről, mint azt Benedek feltételezi. Igaz - ismeri be Nuland -, van „néhány apró tévedés" a tanulmányában. Attól tart azonban, hogy Benedek félreértette az alaptézisét, tudniillik, hogy Semmelweis „az az ember, akit nem a valóság győzött le, hanem az általa a valóságról alkotott elferdített (distorted) koncepciója”. Nuland nem reagált Benedek Alzheimer-kórt elutasító véleményére.

E levélváltást követően jelent meg 1988-ban a már többször említett „Doctors...” című munkája. Ennek Semmelweisről szóló fejezetéről írt ismertetésében Gyukits György megjegyzi: „Prof. Nuland a Semmelweisdoktrínát meglehetős korrektséggel igyekszik ismertetni, esszéjét mégsem tekinthetjük elfogulatlan írásnak... Nem csupán Semmelweis személyisége, lelki alkata marad mindvégig érezhetően távoli és lényegében érthetetlen a könyv írója számára, de a személyiségét körülvevő, annak zavarait jogosan vagy jogosulatlanul kiváltó szociális viszonyrendszer plasztikus rajzával is adósunk marad" [9]. A Nuland által sugallt Semmelweis-kép nem csak a magyaroknak nem tetszik. A Semmelweist „amerikai szemmel" bemutató dolgozat szerzője, Putnam, a 2003-as „... the Strange Story”-nak már a címét sem találja szimpatikusnak: „Az én olvasatomban ugyanis Nuland számára nem annyira a történet tünt furának, hanem Semmelweis személye, sőt leginkább ő maga" [10]. Putnam szerint Nulandot valamennyi Semmelweis-írásában egy „prekoncepció” vezette: „Semmelweis a problémák valódi természetet illetően tévedett" (i. h.). Hadd egészítsem ki Putnam meglátását saját véleményemmel: Nuland lényegében abba a verembe esett bele, amelyet Semmelweis számára ásott meg már 1978-ban és amelyet „nyitva tartott” még 2003-ban is. Ez utóbbi könyve magyar változatából idézek: „... sokkal inkább hasonlít az életrajz Szophoklész darabjaihoz, ahol a hôs sorsát az istenek cselekedetei helyett a saját természetében rejlő hübrisz irányítja". Nuland nem részletezi, mit ért pontosan a „hübrisz” szó alatt. Szabatos definíció helyett nézzük meg, mit ért e fogalom alatt az emberi lélek egyik legnagyobb ismerője, Thomas Mann, aki ezt mondatja Settembrini úrral az óceánjáró komfortjáról: „... bizonyos frivol kihívás van ebben a tökéletes kényelemben, valami afféle, amit a régiek hybris-nek neveztek... olyasmi, mint »Én vagyok Babylon királya! « - egyszóval valami búnös" [11]. Nos, ha Semmelweisben túltengett (az ókorban az istenek haragját kihívó) mértéktelen elbizakodottság, önelégültség, ugyanez elmondható Nulandról is a Semmelweisről kialakított véleményét illetően. S nemcsak Semmelweisről, hanem a betegségét a könyvtárban, karosszékben kutatókról is „furán” nyilatkozik: „... Semmelweis kutatói és lelkes hívei az azóta eltelt majd' 150 évben sportot űztek Semmelweis organikus agyi szindrómája (demenciája) diagnosztizálásából. Úgy tünik, a többségük megelégedett azzal, hogy szifiliszről (vérbajról) beszélt" (Nuland, 2013, 172.). S ha Semmelweist a szülészkollégák közömbössége, ellenállása csak megerősíti igazában, hasonló történik Nuland esetében is: „A heves magyarországi ellenvéleményekkel szembesülve annyira megbizonyosodtam az igazamról... Az abban (értsd: az 1979-es esszében) közölt főbb érveimet máig érvényesnek tartom, és igazukról jobban meg vagyok győződve, mint valaha" (Nuland, 2013, 193.). Nos, valahogy így volt meggyőződve Semmelweis is a saját igazáról.

Azt már Benedek is leírta Nulandhoz intézett levelében: alapjában véve örülünk, hogy Semmelweist felfedezte az amerikaiak számára. Aminek viszont nem örülünk, azt a már idézett Putnam így fogalmazta meg: „... az Egyesült Államokban ma a legtöbben éppen Nuland szemével látják Semmelweist. És ez bizony nagy baj” (Putnam, i. m. 197.). Semmelweis - és azt tudatosítanunk kell ma is, a Semmelweis-emlékévben is - jóval több volt egzotikus különcnél. Ami viszont nem baj: 1981-ben Nuland és Györgyey angolra fordították Semmelweis „nyílt leveleit” és azt a korábbi Murphy-féle Etiológia-fordításhoz csatolva a The Classics of Medicine Library sorozatban ki is adták. A kiváló fordítás és az elegáns, reprezentatív kiadás jelentősen hozzájárul Semmelweis életmúvének nemzetközi megismertetéséhez [12].

Sajnos, Nuland 2014. március 3-án elhunyt. Így tőle már nem várhatunk magyarázatot, miért volt számára „különös” (strange) Semmelweis életútja és/vagy személyisége. Ezért nélküle kell megtennünk a Semmelweis-könyveiben szereplő „különös” felvetései kritikai elemzését [13].

\section{Irodalom}

[1] Magyar, I., Zoltán, I.: Once more about Semmelweis's disease (For the last time?). [Még egyszer Semmelweis betegségéről (Utoljára?).] Magyar Nőorvosok Lapja, 1992, 55, 279-281. [Hungarian]

[2] Nuland, S. B.: Doctors, the Illustrated History of Medical Pioneers. Black Dog and Leventhal Publishers, Inc., New York, 2008.

[3] Nuland, S. B.: The Doctors' Plague. Germs, Childbed Fever, and the Strange Story of Ignác Semmelweis. [Fertőző gyógyítók. A gyermekágyi láz és Semmelweis különös története. Ford.: Garai, A.] HVG Kiadó Zrt., Budapest, 2013. [Hungarian]

[4] Zimmermann, H.: In memoriam Elias E. Manuelidis, M. D. (1918-1992). J. Neuropathol. Exp. Neurol., 1993, 62(3), 260.

[5] Twain, M.: Tom Sawyer Abroad. [Tom Sawyer léghajón. Ford.: Révbíró, T.] Móra Ferenc Könyvkiadó, Budapest, 1985. [Hungarian]

[6] Nuland, S. B.: Doctors, the Biography of Medicine. [Lékařství v pruběhu staletí, cseh nyelvre ford.: Kučera, Španihelová, H.] Euromedia Group, 2000. [Czech] 
[7] Somorjainé Csöppüs, T.: A Facsimile Separate Collection in Memory of József Antall. Ferenc Györgyey's Gift for the Semmelweis Medical Historical Museum, Library and Archives. [Fakszimile különgyújtemény Antall József emlékére, Györgyey Ferenc ajándéka a Semmelweis Orvostörténeti Múzeum, Könyvtár és Levéltár részére.] Comm. Hist. Artis Med., 1997-1998, 158-165, 267-272. [Hungarian]

[8] A Discission. Nuland, S. B.: The Enigma of Semmelweis - an Interpretation. Journal of the History of Medicine and Allied Sciences, 1979, Vol. 34, No. 3, pp. 255-272. Review by Benedek, I. and response of Nuland, S. B. Comm. Hist. Artis Med., 1980, 89-91, 332-336.

[9] Gyukits, Gy.: Nuland, Sherwin B.: Doctors. The Biography of Medicine. New York, A. A. Knopf Inc. 1986 (!). Book review. [Könyvszemle.] Comm. Hist. Artis Med., 1988, 121-124, 179180. [Hungarian]

[10] Putnam, C. E.: Semmelweis from an American point of view. [Semmelweis amerikai szemmel.] Comm. de Hist. Artis Med. 2009, 206-209, 193-199. [Hungarian]
[11] Mann, T.: Zauberberg [A Varázshegy. Ford.: Szőllősy, K.] Európa Könyvkiadó, Budapest, 1974. [Hungarian]

[12] Birtalan, Gy.: Semmelweis, I. F.: The Etiology, the Concept and the Prophylaxis of Childbed Fever. Transl. Murphy, F. P. M. D. Edited with commentary and translation of the Semmelweis “Open Letters" by Sherwin B. Nuland, M. D., and Ferenc A. Györgyey. (The Classics of Medicine Library) Birmingham, 1981. Book review. [Könyvismertetés.] Comm. Hist. Artis Med., 1981, 93-96, 284-285. [Hungarian]

[13] Kiss, L.: Nuland, S. B. The Doctors' Plague. Germs, Childbed fever, and the Strange Story of Ignác Semmelweis. Book review. [Fertőző gyógyítók. A gyermekágyi láz és Semmelweis különös története. HVG Kiadó Zrt., Budapest, 2013. Könyvismertetés.] Orv. Hetil., 2014, 155(26), 1047. [Hungarian]

(Kiss László dr., SK-93 008 Csilizradvány 284., Szlovákia e-mail: kiss.agi@panelnet.sk)

\section{A rendezvények és kongresszusok híranyagának leadása}

a lap megjelenése előtt legalább 40 nappal lehetséges, a 6 hetes nyomdai átfutás miatt. Kérjük megrendelőink szíves megértését.

A híranyagokat a következő címre kérjük: Orvosi Hetilap titkársága: Budai.Edit@akkrt.hu Akadémiai Kiadó Zrt. 